\title{
Social Security in a European Perspective
}

\author{
by E. K. Den Bakker * and G.W. de Wit **
}

\section{Introduction}

While in the previous century people who wanted and who could afford protection, relied entirely on private insurance, this century is characterized by the continuous evolution of basic provisions supplied by public authorities. This evolution has taken the form of an ever expanding system of social insurance.

In many cases the early development of social insurance has stimulated private insurance: private coverage alone was often unfeasible because of the high costs involved, but together with social insurance - the impact of which was still very limited - a reasonable degree of protection could be obtained. At a later stage of development, however, social security became more threatening to private insurance because it took over some of its tasks.

We now have arrived at a turning point. Social security, through social insurance, has expanded to a degree that its costs have become too heavy a burden for our community. This effect has been reinforced by both demographic developments (a less favourable age composition of the population) and a changing distribution of incomes due to economic stagnation.

It may therefore be justified to take a closer look at the situation and to investigate in what relation to one another social and private insurance can safe-guard payable and appropriate protection in the next few decades.

In the following study Mr. G.W. de Wit, advisor to the executive board of Nationale-Nederlanden, made an attempt to obtain the necessary insight and a picture is drawn of the paths we in Europe should be following (also in a political sense) regarding social insurance.

\section{The development of social securlty In Europe}

Now that the economy falters, voices are heard from all directions that social security is one of the first things we can no longer afford. Are the causes of this phenomenon to be found in the stagnating economic activity or in social security itself ?

* Chairman of the Executive Board of Nationale-Nederlanden N.V.

** Advisor to the Executive Board of Nationale-Nederlanden N.V. 
We are asking this question just a century after the birth of the first social insurance system. In 1881, the Germany of Bismarck saw the very beginning of it. The Deutsche

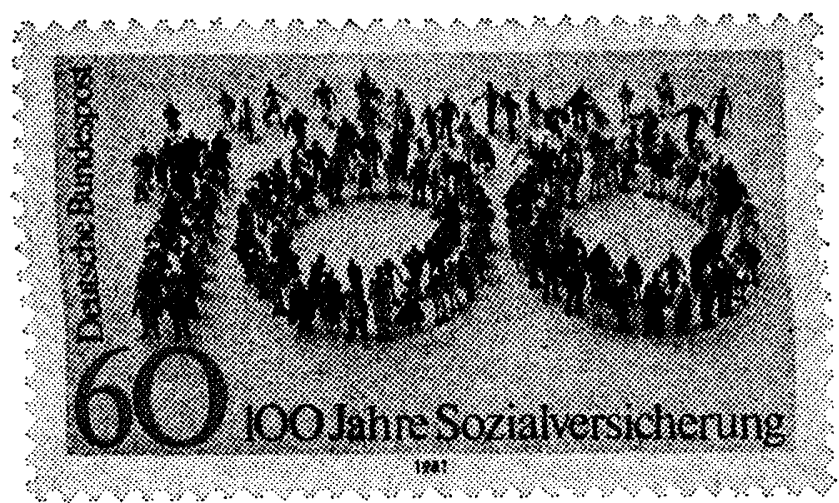
Bundespost was among those who paid attention to this event, by issuing a memorial stamp. Although it probably was not the intention of the designer, he did not only picture the centennial of social security, but also its main problem of today : the ever-increasing use people are making of it.

If voices are heard that we can no longer afford social security, we first have to provide an answer to : "What exactly does it cost?".

Social security expenditure in $\%$ of GDP

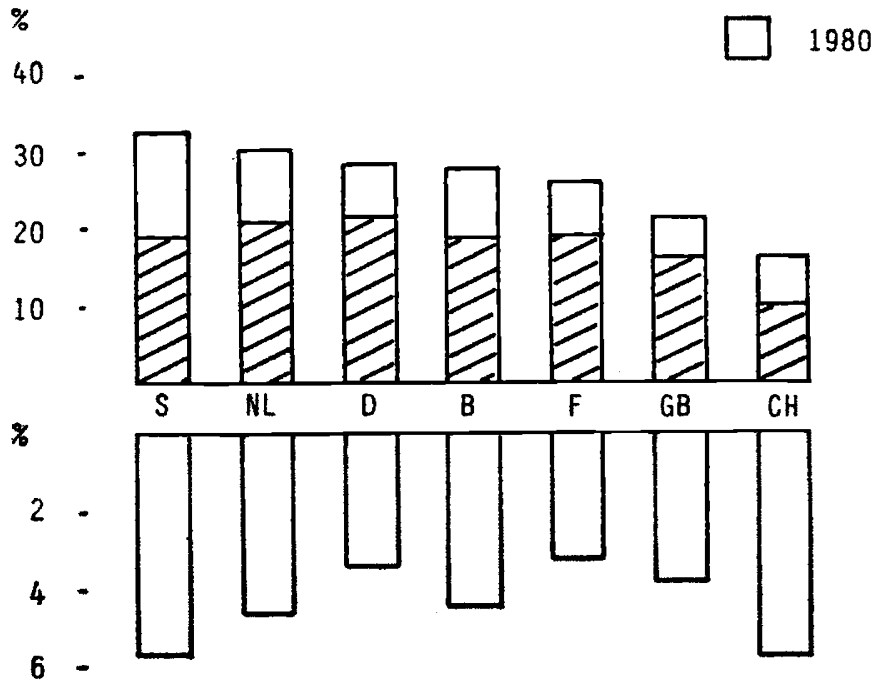

Average annual growth

Fig. 1 
As a percentage of Gross Domestic Product (GDP) the costs of social security in several Western European countries in 1980 range from much below 20 until well above 30 (fig. 1) ${ }^{1}$.

In 1970 several of these percentages were still below 20, with the exception of Germany and the Netherlands. This figure has been increasing at a rate of around $4 \%$, with Belgium and the Netherlands (4.5 and $4.6 \%)$ and Sweden $(5.7 \%)$ occupying the first positions ${ }^{2}$.

It is impossible to assess what the ideal value of this figure should be : it is the product of an evolving society. However, the sharp increase of premiums and other contributions, which is higher than just the combined effect of inflation and a greater prosperity, during a period of an already stagnating economy, is a source of worry.

The social security system has been built up gradually and has followed patterns of development differing from one country to the other. These patterns were determined by political preferences and the nature of society, stressing old age provisions in one country, disability and daily benefits in another, etc.

\section{Social security expenditure in \% of GDP (1980)}

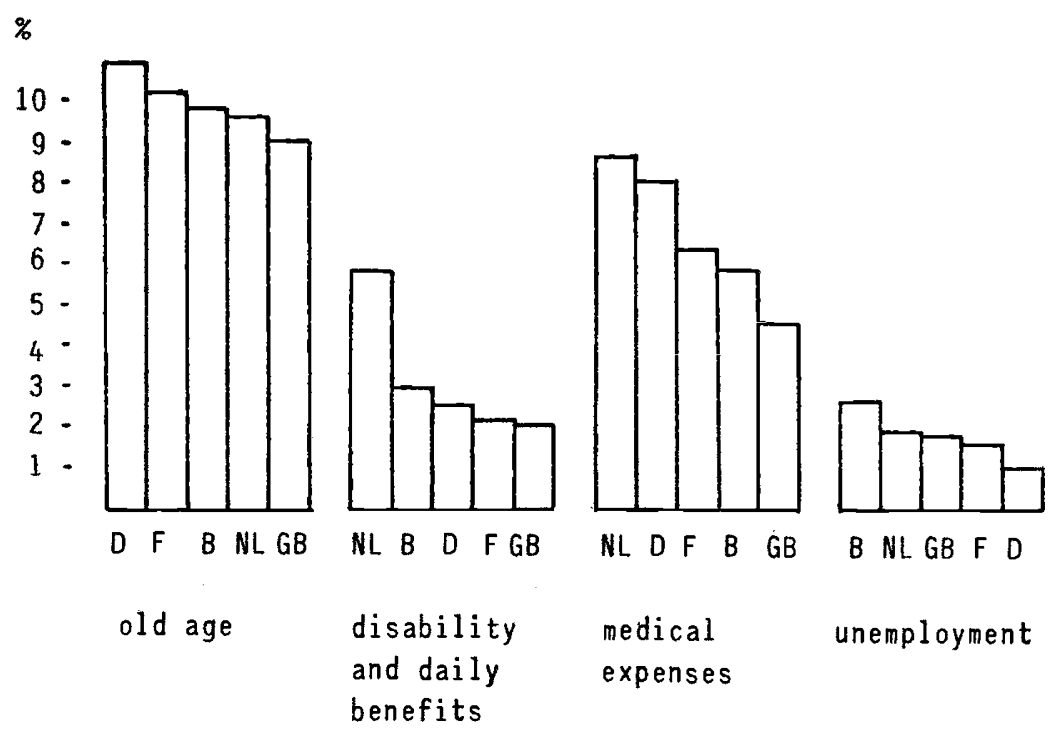

Fig. 2

1 We are using Eurostat's concept of "social protection" (For a definition, see Eurostat, Revue 1971-1980 p. 155).

2 The high average growth of Switzerland is caused by its relatively low position in 1970 compared to other countries. 
In 1980, social security expenditure was fairly equally distributed over its main fields of application (fig. 2).

For the old age provisions the difference between the highest and the lowest figure is $2 \%$ (of GDP), for disability and daily benefits this is only $1 \%$ (at the exception of the Netherlands) and for unemployment just $1 \frac{1}{2} \%$.

The high figure for disability in the Netherlands is explained by the "hidden unemployment " 3 it contains. This sheds a new light on the Dutch expenditure for unemployment which already ranks second after Belgium. In the medical expenses sector the difference is much bigger : well over $4 \%$.

Fig. 2 shows that the pallet of social security is complete in its different sectors, but that there are differences in the importance of certain of its components. This consideration has to be taken into account when plans for changes in social security are being made.

It is very hard to make comparisons in the field of provisions for old age 4 . In all countries but France (60) the retirement age is 65 . In three countries, Belgium, Germany and France, pension benefits are a percentage of income, in the other countries the amounts are more or less a fixed sum. In the Netherlands this fixed sum is higher than the maximum attainable in most other countries, Belgium and France excepted 5 . For the lower incomes the Dutch system is the most favourable one. The most complete pension system is to be found in Sweden, where a basic pension, financed by a pay-as-you-go system, is completed by a pension system based on the number of active years, which is fully capitalized 6 (Almånna Pensionsfonden).

Disability benefits are in many countries of a level comparable to the old age pensions. The degree of disability is $2 / 3$ or $100 \%$ in most countries, the Dutch system with its scale of partial disability starting at $15 \%$ being unique. The Dutch benefits are much higher than in other countries.

Daily benefits range from 50 to $80 \%$ and are always restricted to a maximum. Sometimes, like in France, the percentage goes up when the illness lasts longer. The duration of benefit payment is, generally speaking, one year, often with a deductible of three days.

In all countries full coverage is provided against medical expenses, although some countries work with important deductibles. In France these can be as high as FF 6,000.- It should also be mentioned that the British National Health Service pays no contribution to prevention activities, which are solely supported by private institu-

3 F. A. J. van den Bosch, C. Petersen: "De omvang van de verborgen werkloosheid in de WAO ", Economisch Statistische Berichten 16.1.1980.

4 For an overview of social security see: "Comparative social security tables", 11th edition E.C. (as on July the 1st 1980), a short version of which appears in Appendix 2.

5 For a thorough comparison: "Die AHV im internationalen Vergleich", Neue Zürcher Zeitung 26.5.1982.

6 L. Lagerström : “ Social security in Sweden ", Ed. of the Federation of Social Insurance Offices, September 1976. 
tions. Full medical expenses coverage supplied by private insurance companies exists only in the Netherlands and in Germany ( 30 and $10 \%$ of the population respectively).

For unemployment, the benefits are usually between 60 and $70 \%$ of income; they are to be paid during a limited period, in all countries except Belgium where payments continue until age 65. This explains the fact that Belgium has the highest unemployment expenditure, followed by the Netherlands, where after having received unemployment benefits during one year, people fall back to social assistance, the minimum of which is comparable to the regular unemployment benefit payable in other countries.

Total expenditure for social security has increased during the past ten years at a considerably higher rate than GDP. Even the increasing level of prosperity (which is expressed in the GDP figure) has not been able to keep pace with the extra increase of social security above inflation (fig. 3).

Increase of social

security expenditure

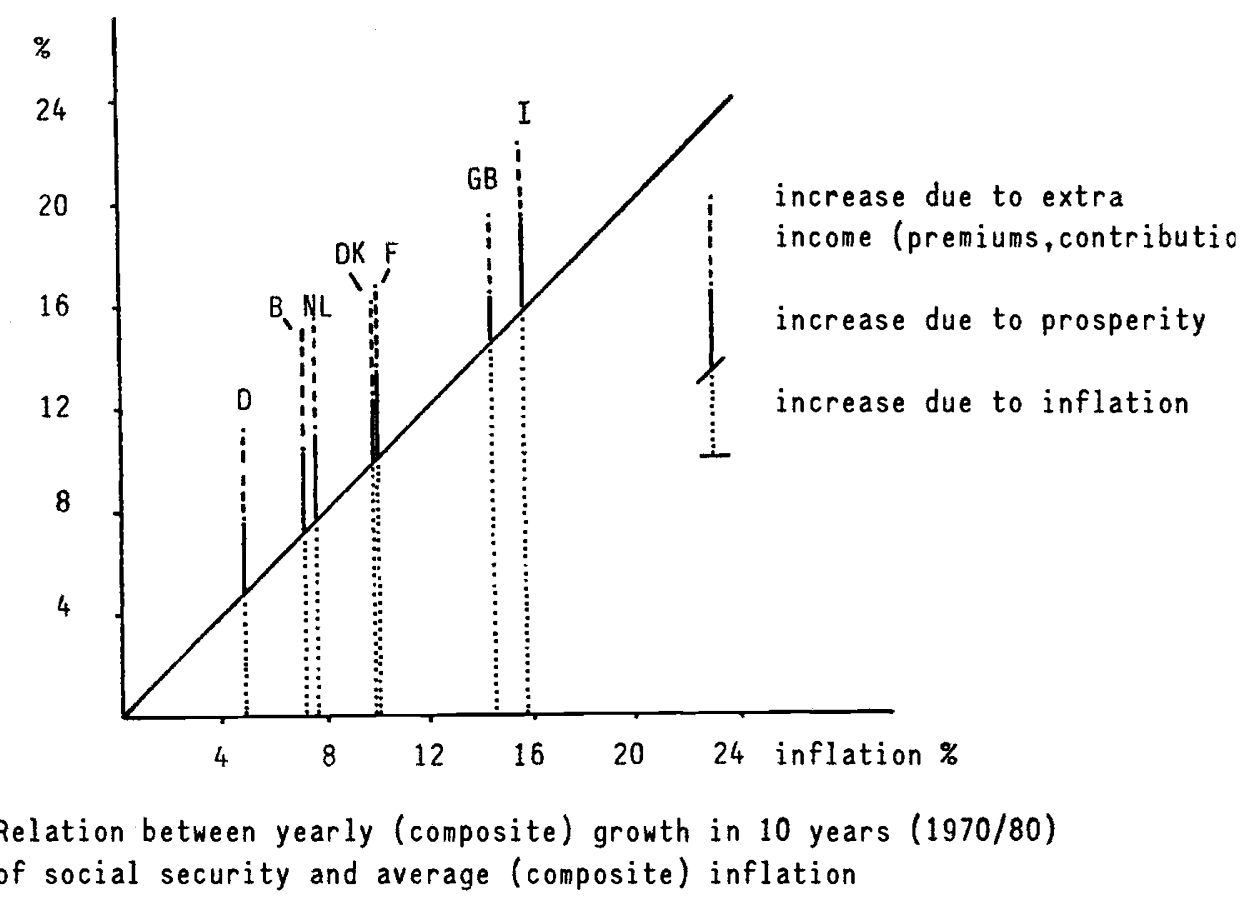

Fig. 3 
A long striped part in this figure means a high growth of social security expenditure above inflation and prosperity. This extra part is between 3.1 and $3.8 \%$ in all countries, except the Netherlands and Belgium (around $4.5 \%$ ). This illustrates that an increasing part of personal income is being channeled through social security.

The growth rates per sector of social security vary considerably during this same 10 year period (fig. 4).

Yearly (composite) grouth of social security sectors (1970/80)
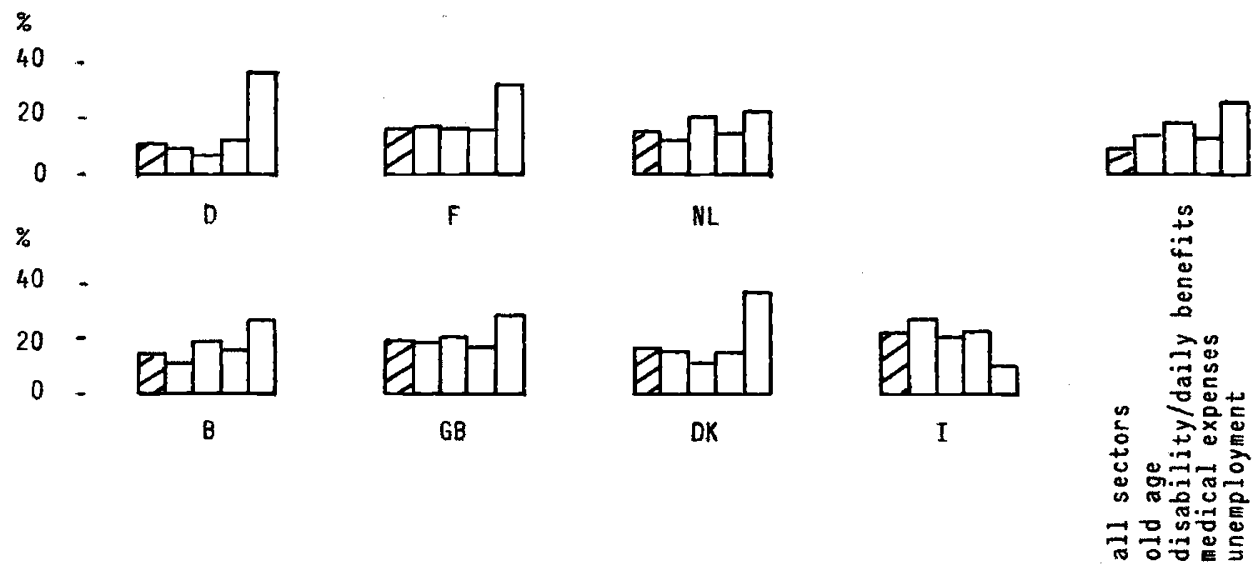

Fig. 4

The growth of unemployment benefits is the highest for all countries except Italy. In the Netherlands a part of this growth for unemployment is expressed by the disability figure which is high too, due to " hidden unemployment" mentioned earlier.

The part private insurance plays in all this is a modest one.

Unemployment insurance is not a task for insurance proper, while in many countries disability insurance is legally linked to life insurance, which considerably slows down its development (the Netherlands, Belgium and the United Kingdom are exception). The influence of private insurance on pension plans is the largest in the Netherlands, in some other countries (like Germany) its importance is increasing, but in others it remains very small (France and Sweden). Private medical expenses insurance is important in the Netherlands and Germany only ; in other countries it is restricted to providing additional coverage to what is offered by the state system or extra coverage for treatment in private hospitals (United Kingdom). No private medical expenses insurance exists in the Scandinavian countries (cf. Appendix 3). 


\section{Basic philosophies}

How did all this come about?

To answer this question we have to go back to the investigation of the philosophy of social insurance. Such a philosophy does exist, in spite of what one might conclude from hearing the present political discussions about cost control.

The origin of social security is to be found a century ago. On November 17th 1881 a kaiserliche Botschaft ${ }^{7}$ was issued, which formed the basis of three social laws made in the eighties of that century. Some important points from the initial years 8 :

- Benefits were related to income.

The provisions were meant for salaried workers as a protection against loss of income.

- Costs were to be covered through premiums paid by both employee and employer. A deliberate choice for an insurance system.

- Financing was done by a pay-as-you-go system.

First mention is made of an "Agreement of solidarity between generations" which Bismark in 1881 expressed as follows :

"The interchangeability of individuals is irrelevant, and the so-called injustice is similar to the one we find with all government institutions, where burdens have to be carried in the present, to the advantage of the future and vice versa " 9 .

These basic principles had an important impact on the development of social insurance in continental countries during the following decades. The United Kingdom however remained untouched by the Bismarck-principles. Their dislike of the development on the continent is well expressed in an article in the Times of 1889 : "Natural as free individual development is to the English in their island home, equally necessary is for Germans a rigid, centralised, all pervading state control... how exceptionally is Germany fitted to be the scene of this great philanthropic experiment. Self-help and spontaneous growth are better suited to Englishmen ".

Meanwhile these ideas remained the basic principles for social insurance. A new sound is heard during the years of crisis. In 1934 Roosevelt, for the first time, launches the concept of "social security" in the context of the New Deal. In 1935 this is followed by the "Social Security Act" ${ }^{10}$, which announces a series of measures to be taken to provide income and purchasing power guaranties. After the war (1948) the concept is adopted in the Declaration of Human Rights and the International Labour Organization develops minimum requirements in 1952. In quite a short time the " social security" concept finds itself well-established!

7 "Die kaiserliche Botschaft. Vor einem Jahrhunderttag" in : "Arbeits- und Sozialpolitik" (1981), p. 219 ff.

8 For a general overview : “The evolution of social insurance, 1881-1981 ”, London 1982.

9 Die kaiserliche Botschaft ; loc. cit. p. 221 and 222.

$10 \mathrm{Cf}$. W. Ackermann : "Soziale Sicherung in der Industriegesellschaft ", I.VW-Schriftenreihe Nr 5, Bern 1980 ; especially p. 23 for literature concerning this development. 
The clearest impact of the concept can be found in the United Kingdom, where the Beveridge-plan ${ }^{11}$ appears in the war year 1942. The heart of the plan is § 303-309 12:

- Fixed benefits for old age, disability and unemployment, for everyone (irrespective of other sources of income).

- A fixed contribution for everyone.

- A simple administration, i.e. a Social Insurance Fund, which controls income and expenditure. For financing the pay-as-you-go system is adopted.

- Benefits must provide an acceptable minimum income (which implies regular adjustments).

The Beveridge-plan was a minimum plan and not more than that. It was to provide protection against poverty. It represented the principle of need. Naturally, the Beveridge-plan has had its greatest impact on the development of social insurance in the United Kingdom ${ }^{13}$. But continental countries have also been under its influence, although in Germany and Italy, the Axis-powers of World War II, its conclusions have not been implemented until the end of the fifties ${ }^{14}$.

The Beveridge-plan was the origin of popular insurance. It forced politicians to take a standpoint on the "social minimum". The choice between a financing system via the general budget or via special premiums has been in favour of the former in all countries, except Denmark, where social insurance is fully fiscalized.

During the following decades, social security carried by the waves of booming prosperity, expands enormously. This causes a slow merger of the Bismarck (loss of

11 W. Beveridge : "Social insurance and allied services", HMSO, November 1942.

$12 \mathrm{~W}$. Beveridge; loc. cit. p. 121 and 122 :

- "The first fundamental principle of the social insurance scheme is provision of a flat rate of insurance benefit, irrespective of the amount of the earnings which have been interrupted by unemployment or disability or ended by retirement. This principle follows from the recognition of the place and importance of voluntary insurance in social security".

- "The second fundamental principle of the scheme is that the compulsory contribution required of each insured person or his employer is at a flat rate, irrespective of his means. All insured persons, rich or poor, will pay the same contributions for the same security ; those with larger means will pay more or only to the extent that as tax-payers they pay more to the National Exchequer and so to the State share of the Social Insurance Fund ".

- "The third fundamental principle is unification of administrative responsability in the interests of efficiency and economy. All contributions will be paid into a single Social Insurance Fund and all benefits and other insurance payments will be paid from that fund ".

- "The fourth fundamental principle is adequacy of benefit in amount and in time. The flat rate of benefit proposed is intended in itself to be sufficient without further resources to provide the minimum income needed for subsistence in all normal cases. It gives room and a basis for additional voluntary provision".

- "The fifth fundamental principle is that social insurance should be comprehensive, in respect both of the persons covered and of their needs".

- "The sixth fundamental principle is that social insurance, while unified and comprehensive, must take account of the different ways of life of different sections of the community".

13 J. Keithley : "L'évolution de la sécurité sociale anglaise depuis le rapport Beveridge ",

Droit Social, 1979, p. 313 ff.

14 W. Ackermann; loc. cit. p. 24. 
income) and Beveridge (basic needs) principles. In the United Kingdom, the fixed contributions were replaced by income-dependent ones in 1966 : "The introduction in 1966 of earnings-related supplements to the short-term benefits constituted perhaps the most important step away from the Beveridge notion of needs-related provision to the Bismarckian concept of earnings-related indemnity" 15.

As a logical consequence of this development, a proposal was made in the EEC in 1966 to build up social security in three sections ${ }^{16}$ :

- basic provisions for everybody, based on personal needs, basic health care and a minimal welfare protection;

- a supplementary system of collective agreements, based on mutual equality with insurance companies ;

- a free system of provisions, fully capitalized, by profit-making institutions. piliers).

This system has become effective in France and Switzerland (système des trois

The most elaborated example of it is to be found in the Swedish pension system.

This expansion of social security, made possible by the quick growth of prosperity, has helped to build the "Welfare State", which had been foretold as early as 1941 17.

Today, in 1982, this Welfare State is in crisis, which was the subject of a recent conference of the OECD ${ }^{18}$.

Before directing our attention towards the remedies one tries to find to fight this crisis of social insurance, we first want to make a few remarks about its fundamental problems.

Two factors have allowed the strong development of social security : first of all growing prosperity which provided the necessary funds, but also the method of financing itself made a contribution. Bismarck, in adopting the loss-of-income principle, already chose the pay-as-you-go system. The Beveridge philosophy, with its aim to guarantee the provisions of one's basic needs, adopted it as well. Since then, practically all forms of social insurance are financed by a pay-as-you-go system. This facilitated the expansion of social security, because it thus became possible, upon extension of benefits, to give everyone the advantage of these immediately, including those persons who had never been paying any premiums or who had paid for a more restricted coverage. These possibilities were related to the growing welfare by the argument that persons who had helped to build up prosperity during the post-war years, should also be able to benefit from it.

15 "The evolution of social insurance 1881-1981"; loc. cit. p. 240.

16 J. J. Dupeyroux : "Evolution et tendances des systèmes de sécurité sociale des pays membres des Communautés Européennes et de la Grande-Bretagne"; un rapport publié par le ESKG, Luxembourg, 1966.

17 "In place of the concept of the power state we are led to that of the welfare state", Archbishop William Temple in 1941.

18 "The welfare state in crisis"; an account of the Conference on Social Policies in the 1980s, Paris, October 1980 (published in 1981 by the OECD). 
Even when social security got to consist of more than providing the minimum basis of life, one continued to passionately defend the pay-as-you-go principle. The German ex-minister Ehrenberg wrote ${ }^{19}$ :

"From a nation-wide economic viewpoint, only one way of financing social security is possible : the pay-as-you-go system, which is making payments using the funds raised in the same period. Dynamic provisions which follow economic development, cannot be financed through saving by their very nature. Clearly, this basic reasoning has not been understood by those critics who still think that insurance against future risks and provision for needs to come by saving capital is possible for the collective just like it is for private persons.

Economically speaking, social security is a redistribution of the Domestic Product or National Income. In other words, by giving up part of their consumption the economically active make consumption by beneficiaries of social insurance possible in doing so, the economically active trust that the next generation will do likewise".

Two points are proven by this defense of the pay-as-you-go system : it relies on growing prosperity in the long run and on the trust that the next generation will pay back its debt to the present one. This last part is essential. For the pay-as-you-go system does not yield any rights, it just creates expectations. The back side of the possibility of beneficiaries to take immediate advantage of any extension of benefits, is the difficulty to partly or wholly abolish existing expectations.

Using a pay-as-you-go funding system creates expectations, one does not only call upon the next generation, but on the following ones as well, thus it is drawing a bill on eternity. No economic or financial system has eternal life, this simple reason implies that failure will arrive sooner or later. But there are so many advantages to a pay-asyou-go system that in the present we can live quite comfortably with it.

Which are the factors that influence the pay-as-you-go system ?

- inflation,

- the level of economic activity,

- demographic changes.

The influence of inflation is essential, benefits payable should be adjusted to the rising price level. Thinking of the equilibrium of generations and its continuation, this adjustment of benefits belongs to the very heart of the pay-as-you-go system. However, it is necessary that the index of adjustment moves parallel with the incomes which generate the expenditure. In all countries adjustment mechanisms are in existence ; they may be automatic (in the Netherlands for instance) or dependent upon a yearly decision (like in the United Kingdom). Essentially, the adjustment should be automatic, but the mechanism should be chosen very carefully.

19 H. Ehrenberg, A. Fuchs : "Sozialstaat und Freiheit ; von der Zukunft des Sozialstaats, Frankfurt am Main 1980, p. 227-229. 
It is therefore surprising to see that so many people are opposed to indexation. Even socialists (who usually defend indexation) do this, like Shirley Williams in a speech "Wohlfahrtspolitik in westlichen Demokratien" held in Zurich on September 14th 198220 who strongly spoke out against the indexation of annuities, because this would mean loosing a weapon against inflation. But the mechanisms themselves must be re-gauged regularly. Much attention is being paid to these problems in Switzerland 21.

When thinking of the changing level of economic activity, attention has almost exclusively been focused on economic growth. Even lower growth rates or stagnation do not seem to cause much worry about the functioning of the system. To quote Ehrenberg 22 :

"The pay-as-you-go system remains valid as the heart of the financing of social security even in presence of lower growth rates or stagnation. The relation between social benefits and the general development of income basically takes care of the balancing of income and expenditure of social security funds, also if personal incomes should no longer increase".

Nevertheless, this reasoning is short-sighted. No one ever had the intention of translating the diminishing financing power, caused by a decreasing number of active working for an increasing number of inactive, into the level of benefits. In Germany people are justly standing up against these light-hearted opinions ${ }^{23}$.

It is virtually impossible to make predictions about economic development, but it should be clear to everyone that one should count with ups and downs in the development of prosperity. Nevertheless, no country set up any reserve in times of great prosperity, like a good entrepreneur aiming at the continuity of his business.

We finally arrive at demographic developments. Unlike economic forecasts, demographic predictions, like assessing the number of aged in the future, are possible with a certain degree of precision.

The recent demographic development has effects which are similar to those of the economic one : a decreasing number of active have to work for an increasing number of inactive. This development endangers the pay-as-you-go system : the percentages of income payable for social security have to increase. In some countries, provisions have been made by setting up important reserves in parallel with the pay-as-you-go funding. The disadvantage is that these reserves are presently being used for other purposes.

20 Neue Zürcher Zeitung 17.9.1982.

Fabius ("The economy and social security in a period of inflation and recession", International Social Security Review, XXIX, 1976, p. 215) has a completely opposite view on the matter.

21 Cf. "Fragen zur offiziellen Korrektur der Indexberechnung" and " Entwöhnung von der Indexgehörigkeit", in Neue Zürcher Zeitung 22.9.1982.

22 H. Ehrenberg, A. Fuchs; loc. cit. p. 237.

23 R. Mehrlein : " Griff in die eigene Tasche", Hamburg 1980, chapter 4 : " Die Dynamik der Sozialkosten und ihre Finanzierungsmöglichkeiten". 
In all countries politicians hardly paid any attention to the many repeated warnings, that especially pensions would become an unbearable burden ${ }^{24}$. In Germany the costs for pensions would amount in 2030 to a level between 32 and $35 \%{ }^{25}$.

The comforting views of some people, that both economic and demographic developments can be solved by pay-as-you-go financing, lead the way in the seventies to certain paths which started to live their own life, based on their own philosophy. That is using the financing of social security as an instrument for other social purposes, like the redistribution of incomes.

Deficits in social accounts are covered by increasing the upper-limits of premium payments, or by increasing the contribution of the Central Government, causing a more pronounced shift in income distribution than a simple increase of premium percentages. These measures thus serve two causes: securing the financing of social security and redistributing incomes.

A final remark about the social minimum. Fundamentally the Beveridge-plan incited to develop a basic philosophy about this concept. This has not been achieved in virtually all countries ${ }^{26}$. A minimum amount does exist for several social benefits, but this often represents so little that we can hardly speak of the minimum for existence. In this regard the position of the Netherlands with its minimum provision is unique in Europe, especially upon considering the level of this minimum.

As a conclusion to this philosophy, I think I can say that the financial crisis of social security has its main roots in the method of financing, which is unable to cope with economic and demographic developments. Furthermore, the other uses that have been made of social security finances have aggravated the crisis.

It will be impossible to keep the present situation unchanged, but it would be unwise to abolish all adjustments because of the deficits which are now being caused by economic and demographic effects. Other solutions will have to be found!

\section{The future}

Social security is becoming an unbearable burden ; the method of financing cannot improve the situation in a stagnating economic environment ${ }^{27}$, all this does is raise the question: what to do ?

Social security has gone through several phases : protection against loss of income, guaranteeing people's basic needs and finally a mixed system. At the end of this 100 years era, it would be desirable to reconsider the main function and goals of social

24 It is surprising to see how Ehrenberg waves away these difficulties by saying that this apparent danger is not a real one. In an aging society, many other burdens disappear. One should not look at old age pensions alone, but take the whole social budget into consideration (H. Ehrenberg, A. Fuchs; loc. cit. p. 244 ff.). In the Netherlands these voices are being heard too.

R. Mehrlein ; loc. cit. shows that even when making rather optimistic assumptions, things will go well only up to 1994 .

25 H. Ehrenberg, A. Fuchs ; loc. cit. p. 244.

26 The "minimum" concept is not easily defined and may differ from one country to another. This is i.a. shown by "Etude sur les bas salaires", doc. du C.E.R.C. nr 59 (fall 1981).

27 For the desirability of social security in times of stagfiation, cf. L. Fabius; loc. cit. 
security. It is impossible to protect everyone against "all social risks of life", but a return to Bismarckian ideas, to relate all social provisions to labour and salary, is equally infeasible.

Much has changed during these last 100 years and we cannot view social security in isolation from the other sectors of our society. We will have to be accurate in the evolution of interrelations.

My second remark is about long-term planning. Again and again measures are being taken on the basis of short-term, sometimes very short-term considerations. This is a fundamental mistake. Social security does not only deal with next year, not even with several years ahead, but with decades and even complete generations.

Now that social security is an integrated part of social and economic life, political choices will have to be made, but these choices can only be made on the basis of long-term considerations, especially financial ones.

Unfortunately, we find that hardly any attention is being paid to these two fundamental problems. The reconsideration of the principle of social security takes place on a very limited scale ${ }^{28}$. However, it is hard to find any long-term thinking on the subject 29 .

What then are the measures which are being taken ? As mentioned earlier, these are short-term measures intended to have an immediate effect in the fight against rising costs :

- the use of reserves, which have been built up for other purposes ;

- the increase of income, by raising premiums (or the maximum amounts payable);

- the increase of the contributions from the general state budget.

The large deficits of social insurance have been noticed as early as $1977^{30}$. These deficits showed up more clearly during the eighties. Thus the German deficit, for old age provisions only, is around DM 6.5 billion. The French 1981 deficit was FF 40 billion, which in the absence of adequate measures will increase up to FF 120 billion. Some

28 In Sweden one has the intention to re-gauge social security in relation to social welfare. News from Sweden. The Swedish International Press bureau, SIP, vol. $56 \mathrm{nr} 16$ (27.8.1982).

In Switzerland an important document has appeared on insurance technical, financial and social aspects of social insurance ("Die Grenze eines staatlichen Sozialsystems" in die Versicherungsrundschau, Vol. 38 nr 2, February 1983, p. 52).

In the United Kingdom we also find some initiatives.

29 The following quotation from a presentation to the Schweizerischer Handels- und Industrie-Verein on September 17th 1982 by W. Hamm is illustrative :

"In the opinion of the speaker, the main mistake of this welfare state policy is in the shortness of the planning horizon and in the underestimation of long-term side effects of social measures. Because these long-term effects generally become fully apparent after many years, many politicians believe that the warnings against the ultimate consequences of their policy are exaggerated, they always take an extra step in trying out the taxability of the economy and later act surprised when it becomes apparent that all warnings were justified. What is missing in many occidental industrial states is statemanship based on a long-term economic and social vision... While truly few politicians seem to be able to carry out this political responsability, other institutions must take on this task for the sake of our social community".

30 See on gigantic expected deficits J. P. Dumont : “L'irrésistible ascension”, in le Monde 1.2.1977. 
countries remain which have a surplus, like Switzerland, where the SF 938 million in 1981 was used to increase total reserves to a sum of SF 7.7 billion.

In many countries reserves were almost completely exhausted.

There are several additional reasons which cause income from premiums to remain behind rising expenditure :

- The OECD ${ }^{31}$ justly points to the harmful effects for the financing of social insurance of the existence of the "underground economy".

- The occidental world gradually turns towards a " society of subsidies". One should keep in mind however that usually no premium is paid over subsidies received.

Since in almost all cases one sticks to the principle of financing through premiums, it can be useful to see how this premium load is carried by employees, employers and the government (fig. 5).
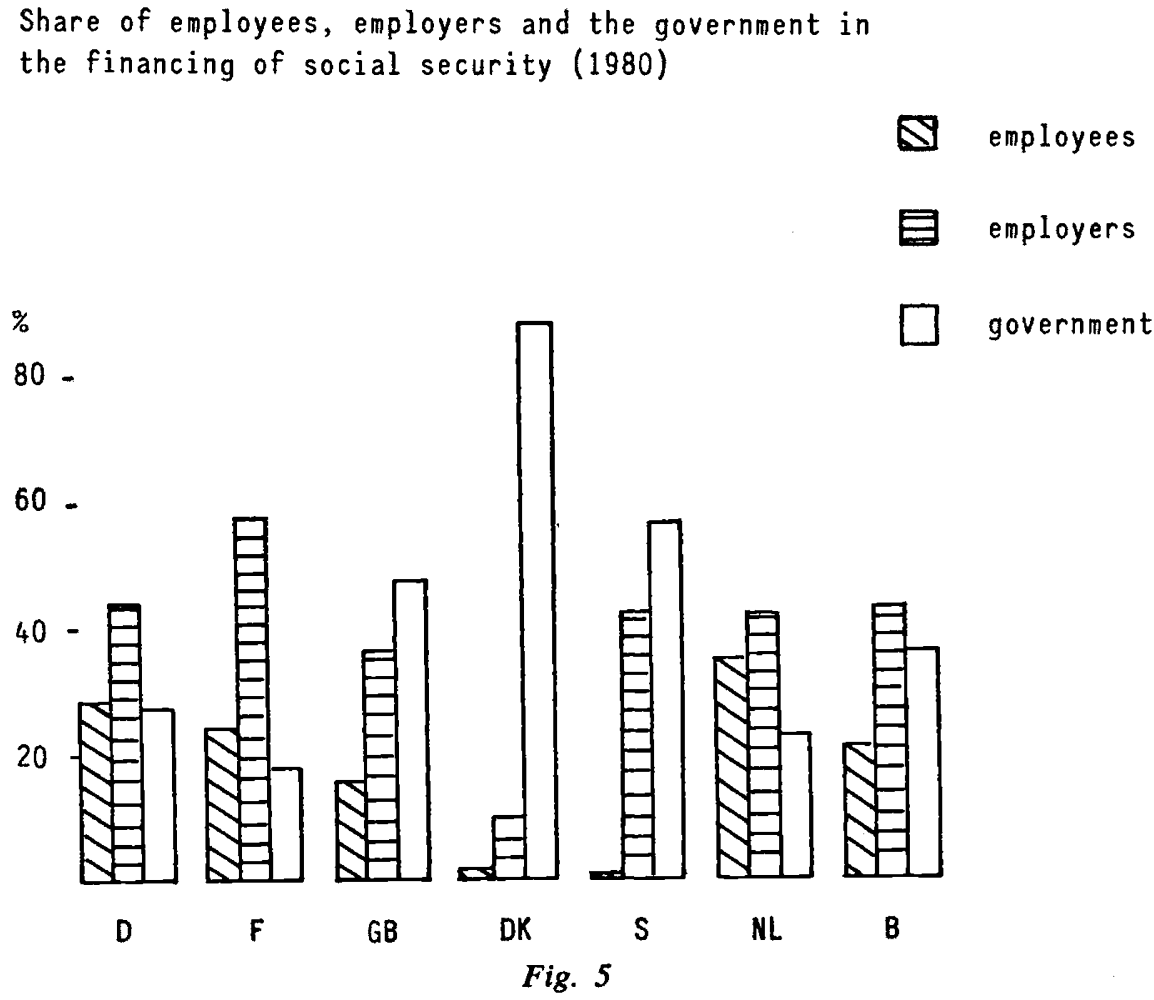

Generally speaking, one can say that employers carry around $40 \%$ of total costs. Only Denmark is an exception; the system is almost fully fiscalized (this has the disadvantage that a deficit is not shown separately, but is part of the total state deficit). France, with its $60 \%$ share for employers, is another exception.

31 “The welfare state in crisis"; loc. cit. p. 159. 
For the other countries the sum of contributions of the government and of employees is almost constant, but the two terms of this sum are very different. In the Netherlands the government contribution is the lowest.

If the possibilities of increasing the contributions of employees (decrease of purchasing power), of employers (too heavy burden for enterprises) and of the government (too big a deficit) are exhausted, what other measures can then be found ?

- Lending on the capital market. This is what is done in Belgium. Naturally this measure is not a cure.

- Transfer towards the employee, not by increasing premiums but by diminishing coverage (deductibles). This measure is very common nowadays ${ }^{32}$.

These are all short-term measures, and again and again the conclusion is : they hardly cure anything.

Social insurance in Western Europe is, in spite of all differences, the best and the most expensive in the world. It is also one of the most prosperous parts of the world.

Social security has decreased the freedom of the West-European individual, his freely disposable income became smaller, it was a source of difficulties for enterprises especially for those which had to compete with the rest of the world. Undoubtedly, the recession has contributed to the cost-increase of this social construction; nowadays one may wonder whether it is recession or social security itself that is to be seen as the main threat.

For both problems a solution will have to be found. The personal responsability of the individual will have to regain an important place. In the light of his relative prosperity, this certainly belongs to the possibilities. The burden of enterprises has to be reduced (one has to keep in mind that employees' premiums and government contributions are also in a sense financed by economic activity).

Luckily, both problems are similar.

We are standing at a turning point in time. The right direction is hard to find, which gives rise to pessimism. This makes us think of Karl Barth's words : "Between the eras, one knows that tradition is of no avail and the old institutions no longer provide us with certainties. One senses the crisis and increases its vigour through unrestrained criticism. Between the eras one does not know what is to come. Moreover, one does not know what should come. This is why between the eras one is strong in negation and weak in positivism (from: "Zwischen den Zeiten ", 1922)."

Let us try to take a positive view. A transfer towards more self retained risk for the insured could be a step in the right direction. It is a pity that this transfer does not take place because of fundamental reasoning - increase of personal responsability 33 - but

32 Clearly visible in the number of days during which daily benefits last and the higher private contributions to medical expenses insurance.

33 One can have discussions on the number of waiting days, on the level of deductibles for employees, on annuity benefits based on gross income or on other constructions. The fundamental question is another one - whether we have the courage to say that each individual must bear part of his own risks himself. Things that were necessary to secure the existence and relieve the needs of people twenty years ago, are no longer a recipe for independent free citizens, who are the best-paid in the world (from : L. Späth : "Aktuelle Fragen der Wirtschafts- und Sozialpolitik", Versicherungs Wirtschaft 1982, $\mathrm{nr}$ 18, p. 1106). 
" nolens volens" to decrease collective expenditure. One does not think of increasing personal responsability, one does not even want to think in that direction. This is clearly shown in France and Belgium where deductibles are very high, but where one has wanted to prohibit the possibility of privately insuring these deductibles. On legal grounds, however, the prohibition was never realized.

Nevertheless, it is here that a way towards the solution can be found. A clear change in mentality will be necessary however. In the fundamental views of social security, as they were described, private initiative and personal responsability played an important part. Due to both the increase of prosperity and the improper use of social security to serve political means, these two basic concepts were lost out of sight. Nevertheless, it should be noticed that wherever private insurance has a task, it performs it well. We will have to renew our choice and look for an equilibrium between social necessity and personal responsability. In countries ruled by non-socialist governments the search for an equilibrium seems to get started more easily than in socialist countries $^{34}$.

To use a variant of a Dutch expression, we can say that in times of recession the " economic shore will make the social ship turn around". The ship is too heavily loaded. With ropes which continually break, some try to keep the cargo on board, while others simply want to throw it in the sea. Both categories are unsuccessful. We have to handle our cargo with utmost care. Let us listen to the pilot who shows the way to a harbour where the ship can unload part of its cargo, which then can be sold in a free market. The ship will then, we hope without being disturbed, continue its journey for many decades.

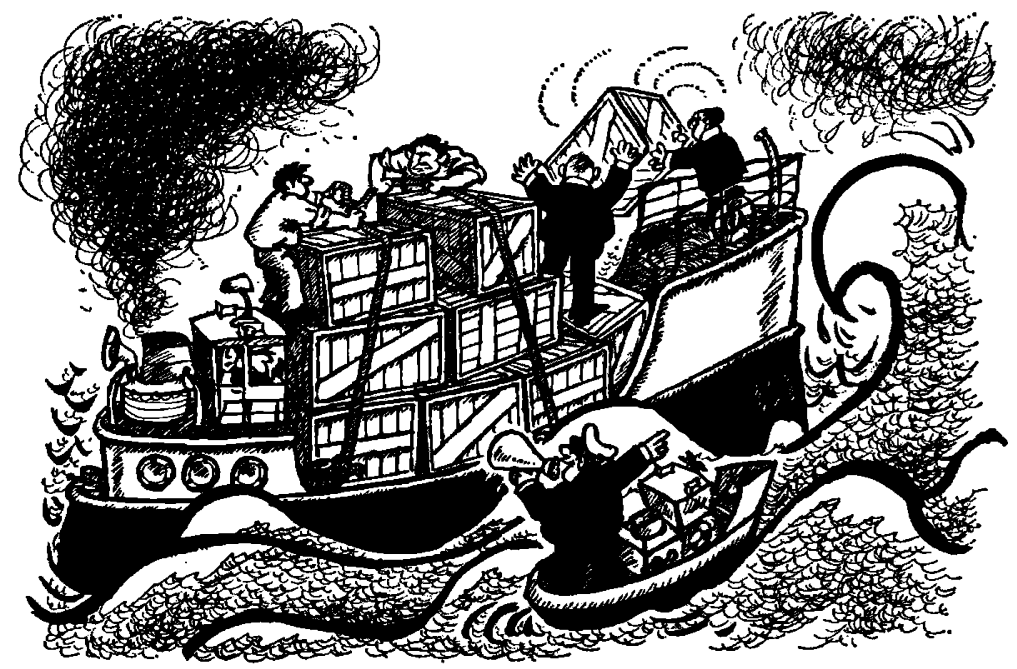

34 At the centennial of social insurance in Germany, von Weiszäcker remarked : "We have to handle this great inheritance cautiously... More personal responsability and less state action, that should be our goal".

The expansion of social insurance in France (pensions) points in another direction. 


\section{Appendix 1}

FIGURES CORRESPONDING TO THE ILLUSTRATIONS

Fig. 1 Social security expenditure in $\%$ of GDP

\begin{tabular}{|c|c|c|c|}
\hline & 1970 & 1980 & $\frac{\text { Average annual }}{\text { growth }}$ \\
\hline Belgium & 18.5 & 27.7 & 4.5 \\
\hline Germany & 21.4 & 28.3 & 3.4 \\
\hline France & 19.2 & 25.8 & 3.2 \\
\hline United Kingdom & 16.3 & 21.4 & 3.8 \\
\hline Netherlands & 20.8 & 30.7 & 4.6 \\
\hline Sweden & 18.8 & 32.6 & 5.7 \\
\hline Switzerland & 10.1 & 16.6 & 5.7 \\
\hline D 1970 & & & \\
\hline ᄀ 1980 & & & \\
\hline
\end{tabular}

Fig. 2 Expenditure of social security per sector in \% of GDP (1980)

\begin{tabular}{l|r|c|c|c} 
& Old age & $\begin{array}{c}\text { Disability }+ \\
\text { daily benefits }\end{array}$ & $\begin{array}{c}\text { Medical } \\
\text { expenses }\end{array}$ & $\begin{array}{c}\text { Unemploy- } \\
\text { ment }\end{array}$ \\
\hline Belgium & 9.9 & 3.0 & 5.9 & 2.7 \\
Germany & 11.0 & 2.6 & 8.1 & 1.0 \\
France & 10.3 & 2.2 & 6.4 & 1.6 \\
United Kingdom & 9.1 & 2.1 & 4.6 & 1.8 \\
Netherlands & 9.7 & 5.9 & 8.7 & 1.9
\end{tabular}

Fig. 3 Relation between yearly (composite) growth in 10 years (1970/80) of social security and average (composite) inflation

\begin{tabular}{l|c|c|c} 
& $\begin{array}{c}\text { Increase due to } \\
\text { extra income } \\
(--)\end{array}$ & $\begin{array}{c}\text { Increase due to } \\
\text { prosperity } \\
(-)\end{array}$ & $\begin{array}{c}\text { Increase due to } \\
\text { infiation } \\
(\ldots)\end{array}$ \\
\hline Belgium & 15.0 & 10.5 & 7.2 \\
Denmark & 16.2 & 12.4 & 9.9 \\
Germany & 11.2 & 7.8 & 4.9 \\
France & 16.8 & 13.6 & 9.9 \\
United Kingdom & 19.5 & 16.4 & 14.3 \\
Italy & 22.2 & 19.4 & 15.6 \\
Netherlands & 15.7 & 11.1 & 7.6
\end{tabular}


Fig. 4 Yearly (composite) growth in 10 years of social security sectors (1970/80)

\begin{tabular}{l|c|c|c|c|c} 
& $\begin{array}{c}\text { All } \\
\text { sectors }\end{array}$ & Old age & $\begin{array}{c}\text { Disability }+ \\
\text { daily benefits }\end{array}$ & $\begin{array}{c}\text { Medical } \\
\text { expenses }\end{array}$ & $\begin{array}{c}\text { Unemploy- } \\
\text { ment }\end{array}$ \\
\hline Belgium & 15.0 & 10.8 & 18.4 & 15.2 & 26.8 \\
Denmark & 16.2 & 16.0 & 11.9 & 15.2 & 37.5 \\
Germany & 11.2 & 9.9 & 7.2 & 12.1 & 36.4 \\
France & 16.8 & 17.1 & 16.8 & 16.5 & 32.6 \\
United Kingdom & 19.5 & 18.5 & 20.9 & 17.3 & 29.5 \\
Italy & 22.2 & 27.5 & 20.9 & 23.2 & 11.1 \\
Netherlands & 15.7 & 13.3 & 21.6 & 15.4 & 23.2
\end{tabular}

Fig. 5 Share of employees, employers and the government in the financing of social security (1980)

\begin{tabular}{l|c|c|c} 
& Employees & Employers & Government \\
\hline Belgium & 21.0 & 42.8 & 36.2 \\
Denmark & 1.8 & 10.0 & 88.2 \\
Germany & 28.4 & 44.1 & 27.5 \\
France & 24.3 & 57.5 & 18.2 \\
United Kingdom & 16.0 & 36.4 & 47.6 \\
Italy & 14.0 & 60.5 & 25.5 \\
Netherlands & 35.1 & 41.9 & 23.0 \\
Sweden & 1.3 & 42.3 & 56.4
\end{tabular}

\section{Appendix 2}

\section{MEDICAL EXPENSES}

\section{Personal contributions}

Belgium

Denmark

Germany

France

United Kingdom

Italy

Netherlands hospitalization costs including treatment : contribution as from the 41st day of treatment

all other treatments : $25 \%$ (except for the disabled and pensioners) medicines : a maximum amount.

Deductibles increase with the simplicity of treatment. A small deductible for hospitalization ( $5 \%), 25 \%$ for treatment, $35 \%$ for special services, until $60 \%$ for "spécialités".

The total deductible amount is maximized (" ticket modérateur ") and is higher for independent workers than for employees. 


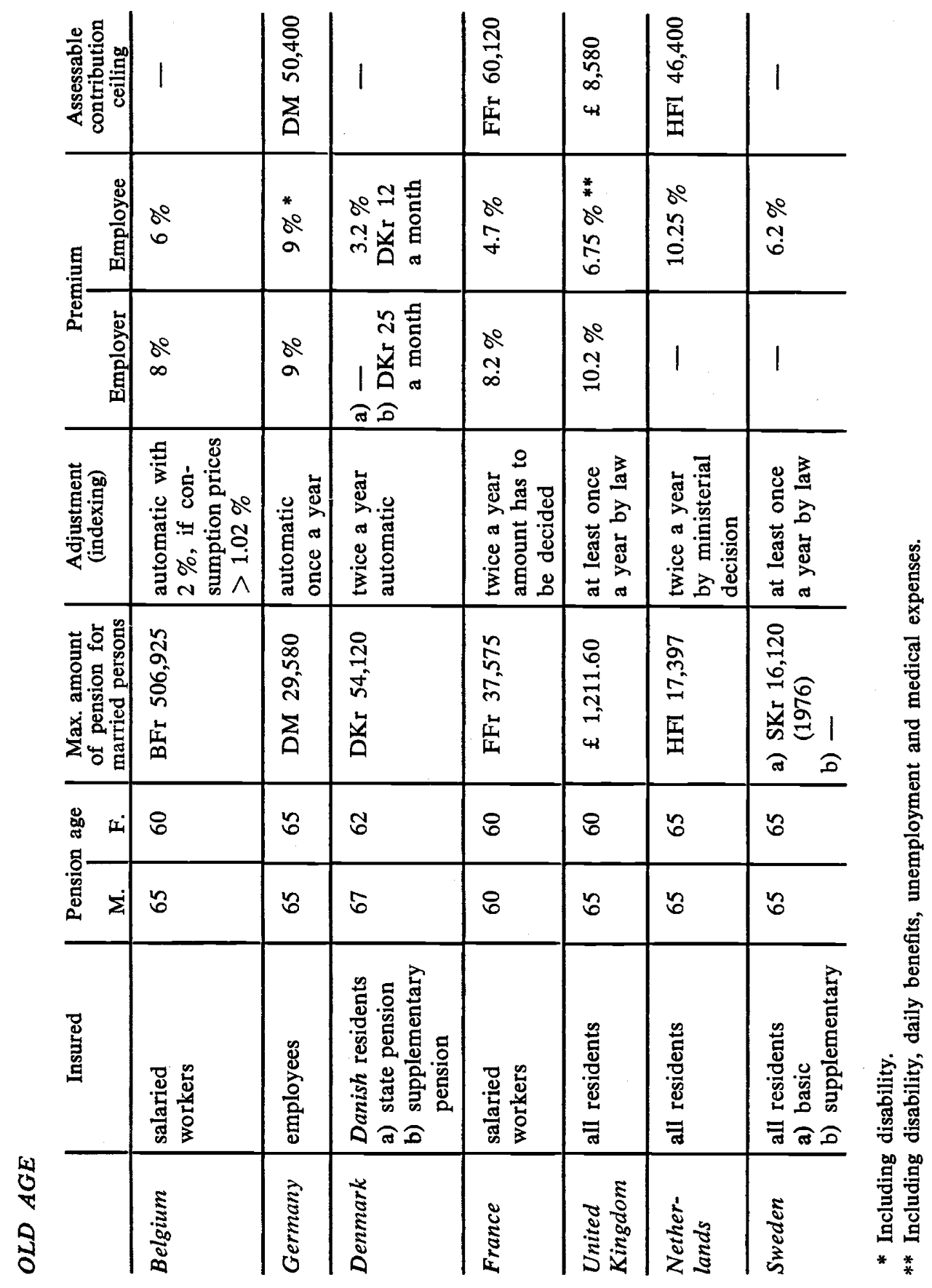




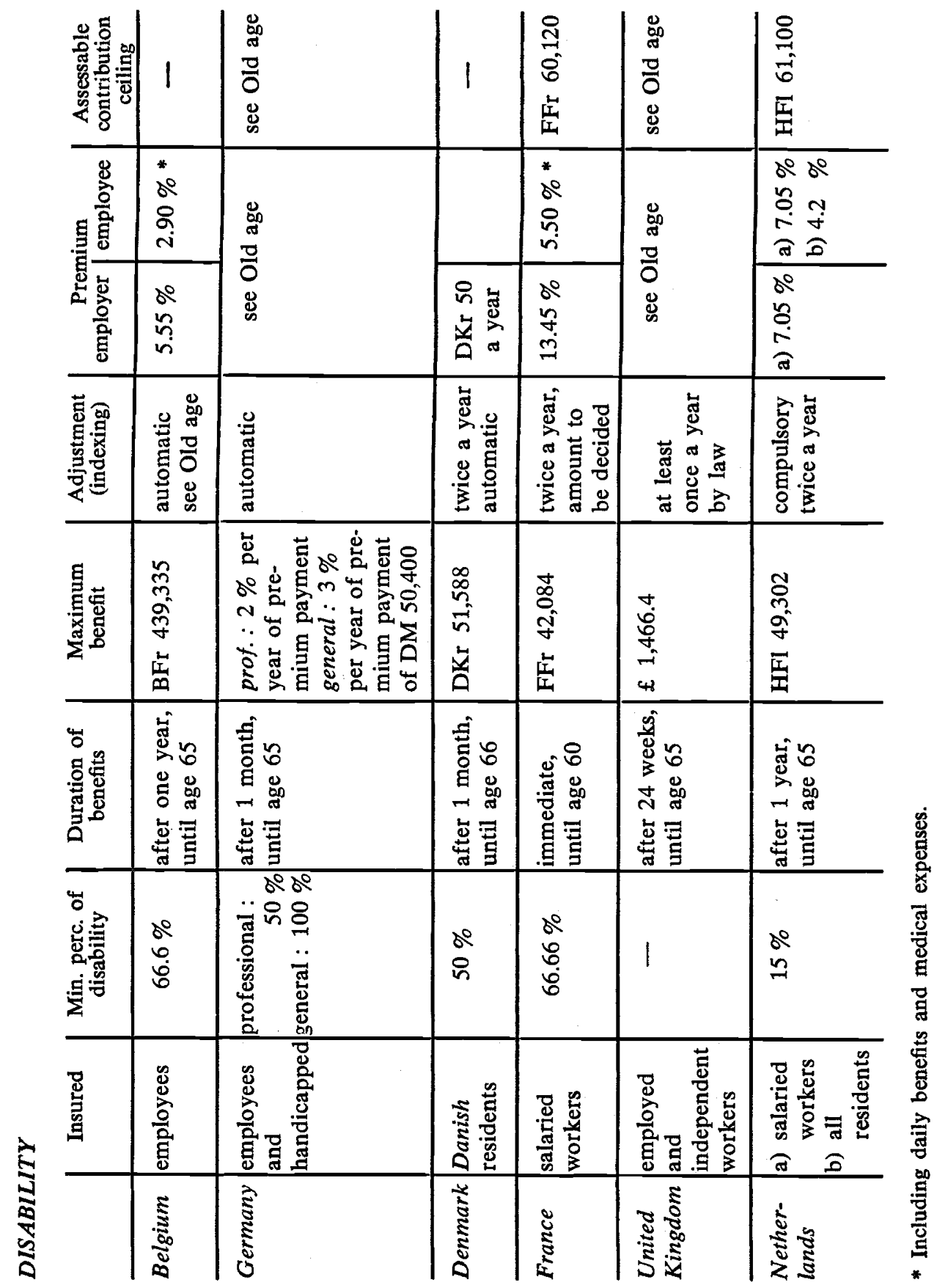




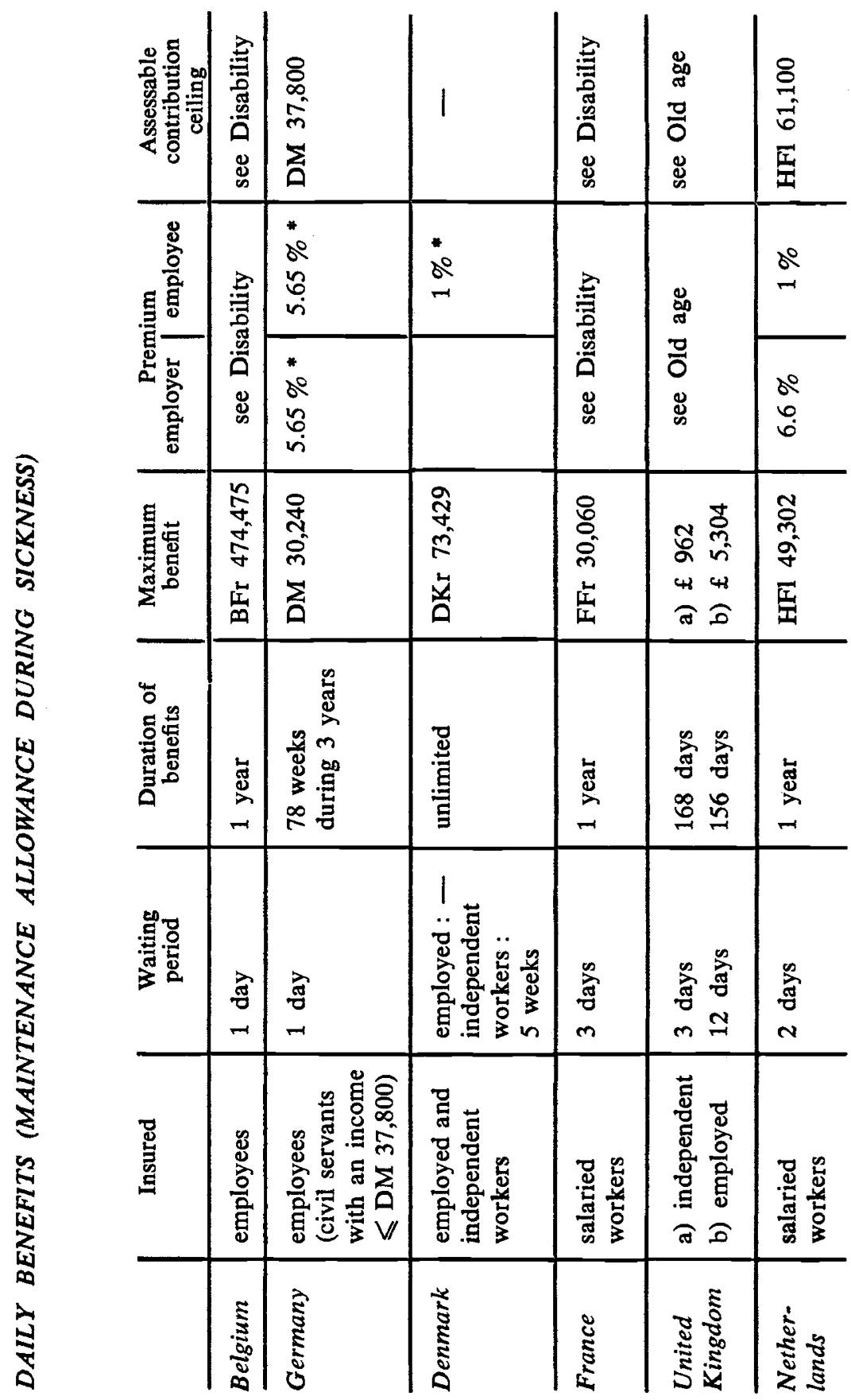

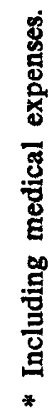




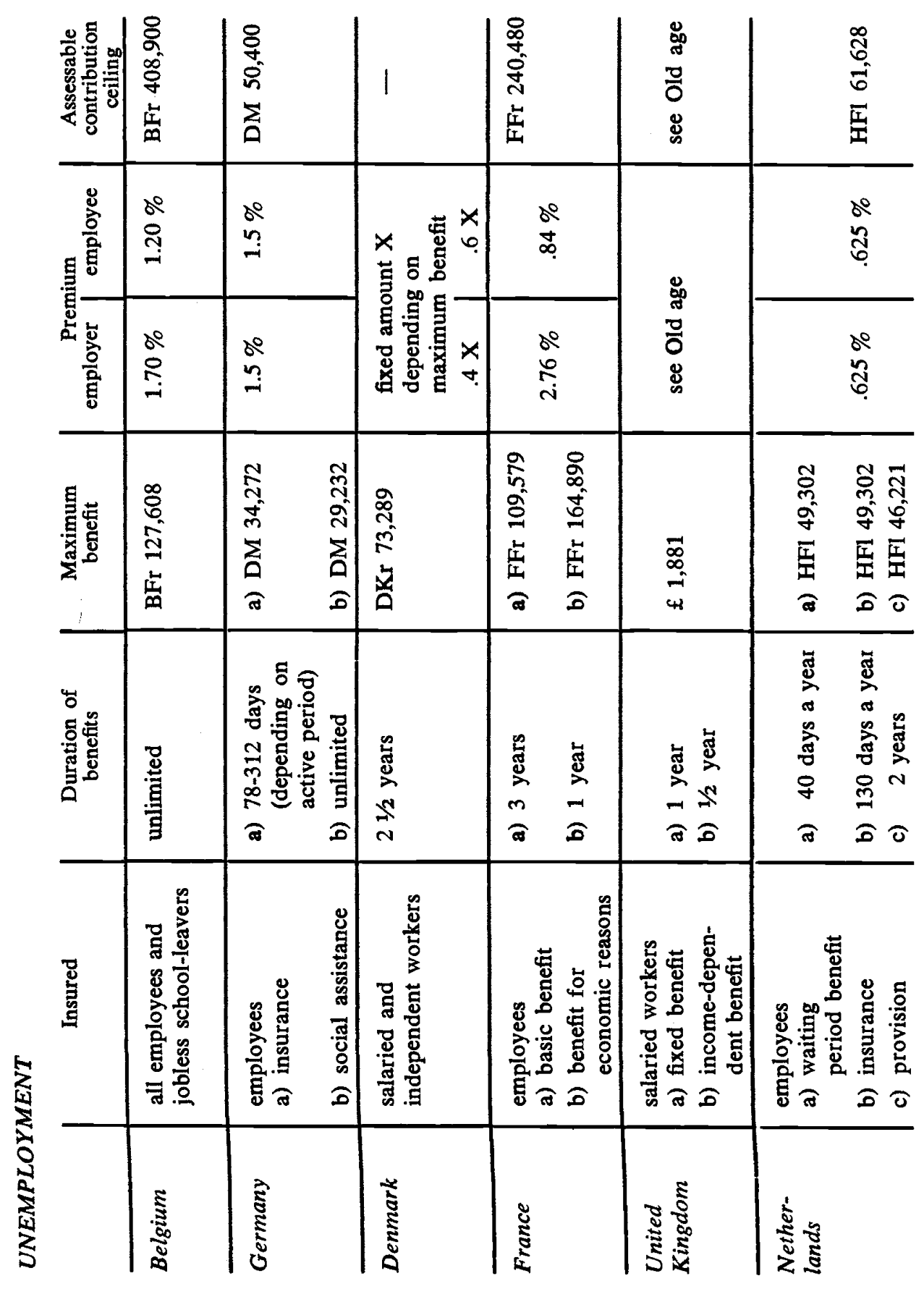




\section{Appendix 3}

APPLICATION FIELDS OF PRIVATE INSURANCE, IN CONNECTION WITH SOCIAL SECURITY

(next to and on top of the provisions mentioned in Appendix 2)

$O L D A G E$

Belgium : pension funds per company or per branch of industry exist, similar to the Dutch ones, but also non-capitalized pension promises made by (associations of) employers.

Germany : although non-capitalized pension promises still exist, an important and increasing part of pensions is covered by insurance companies on a voluntary basis.

France : provisions are made by agreement between employers and employees (" caisses de retraite").

Private insurance plays no important part as a risk-carrier.

United Kingdom : there is an obligation to provide pensions, but employers can be " contracted-out". They then have to buy insurance coverage of at least the same quality from a private insurance company. This possibility is widely used.

Netherlands : - pension provision per branch of industry,

- pensions provided per company,

- individual pension provisions.

Private insurance plays an important part.

\section{DISABILITY}

In some countries (Belgium, United Kingdom and the Netherlands) disability insurance is a more or less important part of the private insurance industry. In other countries the restriction exists that disability insurance may only be sold in combination with a life insurance policy, which greatly impedes its development.

\section{DAILY BENEFITS (SICKNESS MAINTENANCE ALLOWANCE)}

These are in many countries intertwined with other branches of insurance, like :

- benefits per day of hospitalization (Germany, United Kingdom),

- daily benefits can be part of (supplementary) medical expenses insurance (Belgium),

- daily benefits can be looked upon as short-term disability benefits (France). 


\section{MEDICAL EXPENSES}

In the Netherlands, $30 \%$ of the population has full coverage from private insurance. In Germany, $10 \%$ of the population has full coverage from private insurance.

In all other countries everybody is covered by social insurance. In that case, the following functions are left for private insurance :

— insurance of "extras" (first class nursing, supplementary provisions); this takes place in all countries;

- insurance of deductibles; especially in France ;

- insurance of private provisions which exist in parallel with social insurance ("double" insurance); this exists in the United Kingdom to supplement the National Health Service.

In Scandinavian countries, private medical expenses insurance does not exist. 